\title{
A Formal Synthesis of Psymberin
}

\section{Supplemental Information}

Ning Shangguan, Sezgin Kiren and Lawrence J. Williams

Contribution from the Department of Chemistry and Chemical Biology, Rutgers, The State University of New Jersey, Piscataway, New Jersey 08854, USA

General: Starting materials, reagents and solvents were purchased from commercial suppliers (Aldrich, Fischer, Advanced ChemTech) and used without further purification unless otherwise stated. All reactions were conducted in oven-dried (135 $\left.{ }^{\circ} \mathrm{C}\right)$ glassware under an inert atmosphere of argon. The progress of reactions was monitored by silica gel thin layer chromatography (tlc) plates (mesh size $60 \AA$ with fluorescent indicator, Sigma-Aldrich), visualized under UV and charred using cerium or anisaldehyde stain. Products were purified by flash column chromatography (FCC) on 120-400 mesh silica gel (Fisher). Infrared (FTIR) spectra were recorded on an ATI Mattson Genesis Series FT-Infrared spectrophotometer. Proton nuclear magnetic

resonance spectra $\left({ }^{1} \mathrm{H}\right.$ NMR) were recorded on either a Varian-300 instrument (300 $\mathrm{MHz}$ ) or a Varian-400 instrument (400 MHz) unless otherwise stated. Chemical shifts are reported in ppm relative to residual $\mathrm{CHCl}_{3}$ signal. Data is reported as follows: chemical shift, integration, multiplicity ( $\mathrm{s}=$ singlet, $\mathrm{d}=$ doublet, $\mathrm{t}=$ triplet, $\mathrm{q}=$ quartet, br=broad, $\mathrm{m}=$ multiplet), and coupling constants $(\mathrm{Hz})$. Carbon nuclear magnetic resonance spectra $\left({ }^{13} \mathrm{C}\right.$ NMR) were recorded on either a Varian-300 instrument (75 $\mathrm{MHz})$ or a Varian-400 instrument (100 MHz) unless otherwise stated. Optical rotations were recorded at $25{ }^{\circ} \mathrm{C}$ using the sodium D line $(589 \mathrm{~nm})$, on a Perkin-Elmer 241 polarimeter. Mass spectra were recorded on a Finnigan LCQ-DUO mass spectrometer. 


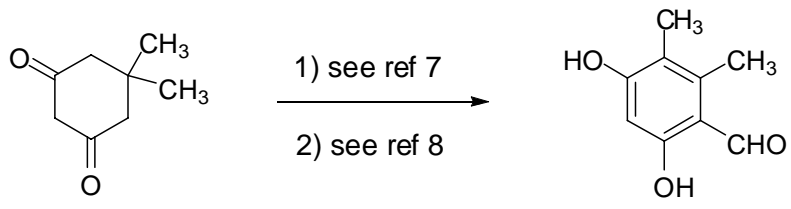

11

12

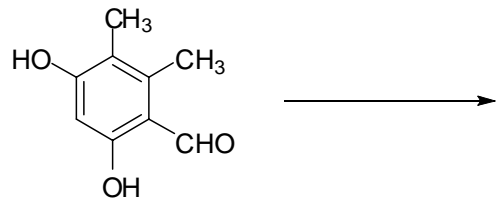

12

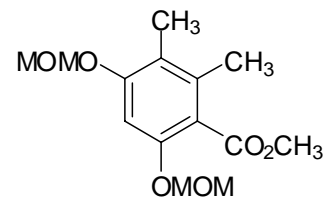

13

To a solution of aldehyde $12(1.65 \mathrm{~g}, 9.96 \mathrm{mmol})$ in DMF $(12 \mathrm{ml})$ at $0{ }^{\circ} \mathrm{C}$ was added Hunig's base $(5.2 \mathrm{ml}, 29.9 \mathrm{mmol})$ and $\mathrm{MOMCl}(2.27 \mathrm{ml}, 29.9 \mathrm{mmol})$. After stirring for $20 \mathrm{~h}$ at room temperature, the reaction mixture was quenched with saturated $\mathrm{NH}_{4} \mathrm{Cl}$ and then extracted with $\mathrm{CH}_{2} \mathrm{Cl}_{2}$. The extracts were dried over $\mathrm{Na}_{2} \mathrm{SO}_{4}$ and concentrated in vacuo. The crude was passed through a pad of silica gel and used for next step without further purification.

A solution of aldehyde (2.4 mg, $9.4 \mathrm{mmol})$ in $120 \mathrm{ml} \mathrm{tBuOH}-\mathrm{H}_{2} \mathrm{O}(1: 1)$ was cooled to $0{ }^{\circ} \mathrm{C}$, to which was added $\mathrm{NaH}_{2} \mathrm{PO}_{4} \mathrm{H}_{2} \mathrm{O}$ (3.38 g, $28.2 \mathrm{mmol}$ ), 2-methyl-2-butene (12.1 ml from $2 \mathrm{M}$ solution in THF, $28.2 \mathrm{mmol})$ and $\mathrm{NaClO}_{2}(3.18 \mathrm{~g}, 28.2 \mathrm{mmol}$ ). After stirring for $4 \mathrm{~h}$, the mixture was concentrated down, extracted with EtOAc and dried over $\mathrm{Na}_{2} \mathrm{SO}_{4}$. The crude was passed through a pad of silica gel and used for next step without further purification.

A solution of acid $(2.48 \mathrm{~g}, 9.2 \mathrm{mmol})$ in THF $(25 \mathrm{ml})$ was treated with $\mathrm{PPh}_{3}(4.82 \mathrm{~g}$, $18.4 \mathrm{mmol})$ and $\mathrm{MeOH}(1.8 \mathrm{ml}, 46 \mathrm{mmol})$ which was then cooled to $0{ }^{\circ} \mathrm{C}$. DIAD ( $3.72 \mathrm{~g}, 18.4 \mathrm{mmol}$ ) was added to reaction mixture. After stirring for $12 \mathrm{~h}$, the mixture was diluted with $\mathrm{H}_{2} \mathrm{O}$ and extracted with $\mathrm{CH}_{2} \mathrm{Cl}_{2}$. The organic extracts were dried over $\mathrm{Na}_{2} \mathrm{SO}_{4}$ and concentrated down under reduced pressure. The crude was purified by FCC using hexane:ethyl acetate (10:1) as eluent to furnish ester 13 (2.43 g, 86\% over 3 steps) as yellowish oil. IR $v_{\max }\left(\right.$ neat) $/ \mathrm{cm}^{-1} 2952,2913,2827,1731,1597,1481$, 1436, 1271, 1153, 923; ${ }^{1} \mathrm{H}$ NMR (400 MHz, $\left.\mathrm{CDCl}_{3}\right) 6.77(1 \mathrm{H}, \mathrm{s}), 5.17(2 \mathrm{H}, \mathrm{s}), 5.13$ $(2 \mathrm{H}, \mathrm{s}), 3.89(3 \mathrm{H}, \mathrm{s}), 3.46(6 \mathrm{H}, \mathrm{s}), 2.18(3 \mathrm{H}, \mathrm{s}), 2.11(3 \mathrm{H}, \mathrm{s}) ;{ }^{13} \mathrm{C}$ NMR $(100 \mathrm{MHz})$ $169.4,156.5,152.6,135.6,120.1,119.5,100.2$, 95.3, 94.9, 56.4, 56.3, 52.3, 17.2, 11.6; $\mathrm{m} / z$ (ESIMS) calculated for $\mathrm{C}_{14} \mathrm{H}_{20} \mathrm{O}_{6} \mathrm{Na}[\mathrm{MNa}]^{+}$307.2, found: 307.2. 


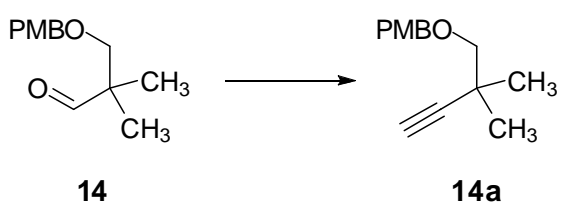

To a solution of $\mathrm{K}_{2} \mathrm{CO}_{3}(24.8 \mathrm{~g}, 180 \mathrm{mmol}), \mathrm{TsN}_{3}(15.3 \mathrm{~g}, 78 \mathrm{mmol})$ in $\mathrm{MeCN}$ (400 $\mathrm{mL}$ ) was syringed dimethyl-(2-oxapropyl) phosphonate $(10.6 \mathrm{~mL}, 78 \mathrm{mmol})$ at $\mathrm{rt}$. After stirring for $2 \mathrm{~h}$, a solution of aldehyde $14(13.3 \mathrm{~g}, 60 \mathrm{mmol})$ in $80 \mathrm{~mL}$ of $\mathrm{MeOH}$ was added. Stirring continued for $20 \mathrm{~h}$, the mixture was concentrated under reduced pressure and then diluted with distilled water. The mixture was extracted with $\mathrm{Et}_{2} \mathrm{O}$ and dried over $\mathrm{Na}_{2} \mathrm{SO}_{4}$. Purification by FCC using ethyl acetate / hexane (1:20) afforded $11.4 \mathrm{~g}(85 \%)$ alkyne as a colorless oil. IR $v_{\max }($ neat $) / \mathrm{cm}^{-1} 3290,2970,2934$, 2100, 1612, 1586, 1513; ${ }^{1} \mathrm{H}$ NMR (400 MHz, $\left.\mathrm{CDCl}_{3}\right) 7.28(2 \mathrm{H}, \mathrm{d}, \mathrm{J}=8.4 \mathrm{~Hz}), 6.88$ $(2 \mathrm{H}, \mathrm{d}, \mathrm{J}=8.4 \mathrm{~Hz}), 4.54(2 \mathrm{H}, \mathrm{s}), 3.80(3 \mathrm{H}, \mathrm{s}), 3.29(2 \mathrm{H}, \mathrm{s}), 2.12(1 \mathrm{H}, \mathrm{s}), 1.23(3 \mathrm{H}, \mathrm{s})$; ${ }^{13} \mathrm{C}$ NMR $\left(75 \mathrm{MHz}, \mathrm{CDCl}_{3}\right)$ 161.8, 159.1, 130.5, 129.1, 113.7, 90.3, 73.0, 68.1, 55.2, 32.2, 26.0. $\mathrm{m} / z$ (ESIMS) calculated for $\mathrm{C}_{14} \mathrm{H}_{18} \mathrm{O}_{2} \mathrm{Na}[\mathrm{MNa}]^{+} 241.12$, found: 241.1 .

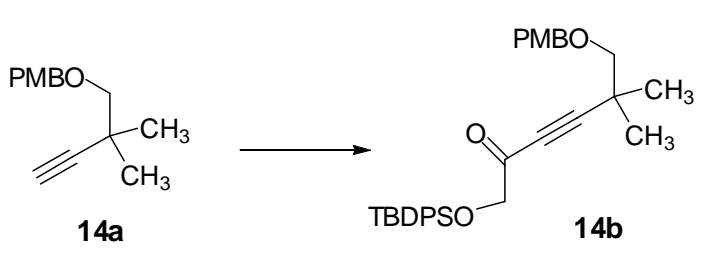

To a solution of alkyne $6.3 \mathrm{~g}, 29.0 \mathrm{mmol})$ in THF $(60 \mathrm{ml})$ was added n-BuLi $(21.0$ $\mathrm{ml}, 33.0 \mathrm{mmol})$ ) at $-78{ }^{\circ} \mathrm{C}$. After warming to $0{ }^{\circ} \mathrm{C}$ and stirring for $30 \mathrm{~min}$, the reaction mixture was cooled to $-78{ }^{\circ} \mathrm{C}$ and a solution of weinreb amide $(12.4 \mathrm{~g}, 34.7 \mathrm{mmol})$ in THF (40 ml) was added slowly. Stirring continued for $20 \mathrm{~min}$ at $-78{ }^{\circ} \mathrm{C}$ and for $1 \mathrm{~h}$ at $0{ }^{\circ} \mathrm{C}$ and then the mixture was quenched with $\mathrm{NH}_{4} \mathrm{Cl}$ solution. The mixture was extracted with $\mathrm{CH}_{2} \mathrm{Cl}_{2}$. The combined organic extracts were dried over $\mathrm{Na}_{2} \mathrm{SO}_{4}$ and concentrated under reduced pressure. The residue was purified by FCC (silica gel, ethyl acetate/hexane 1:10) to give $11.1 \mathrm{~g}$ alkynone (72\%) as a colorless oil. IR $v_{\max }($ neat $) / \mathrm{cm}^{-1} 3068,2950,2925,2200,1696,1673,1612,1513,1427,1110,702 ;{ }^{1} \mathrm{H}$ NMR (300 MHz, CDCl 3 ) 7.70-7.67 (4H, m), 7.44-7.35 (6H, m), $7.23(2 \mathrm{H}, \mathrm{d}, \mathrm{J}=5.4$ Hz), 6.85 (2H, d, J= 5.4 Hz), $4.48(2 \mathrm{H}, \mathrm{s}), 4.29(2 \mathrm{H}, \mathrm{s}), 3.80(3 \mathrm{H}, \mathrm{s}), 3.3(2 \mathrm{H}, \mathrm{s}), 1.25$ (6H, s), 1.09 (9H, s); ${ }^{13} \mathrm{C}$ NMR (100 MHz) 186.3, 159.4, 135.7, 132.9, 130.4, 130.1, 129.3, 128.0, 113.9. 101.9, 78.9, 77.5, 73.2, 70.7, 55.4, 33.2, 26.9, 25.3, 19.5; $\mathrm{m} / \mathrm{z}$ (ESIMS) calculated for $\mathrm{C}_{32} \mathrm{H}_{38} \mathrm{O}_{4} \mathrm{SiNa}[\mathrm{MNa}]^{+}$537.24, found: 537.3. 


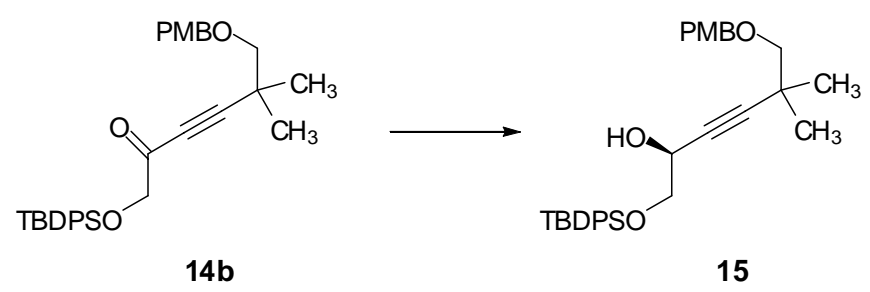

To a solution of Noyori catalyst in $60 \mathrm{ml} \mathrm{iPrOH}$ was added a solution of alkynone $(15.0 \mathrm{~g}, 31.5 \mathrm{mmol})$ in $60 \mathrm{ml} \mathrm{PrOH}$. The mixture was stirred for $30 \mathrm{~min}$, and then was concentrated in vacuo. Purification of the residue by FCC using hexane/ethyl acetate (1:10) furnished $15.0 \mathrm{~g}(98 \%)$ alcohol 15 as a colorless oil. $[\alpha]_{\mathrm{D}}^{25}=-9.6(\mathrm{c}=$ 0.83, $\mathrm{CHCl}_{3}$ ); IR $v_{\max }($ neat $) / \mathrm{cm}^{-1} 3448,3070,2955,2930,2238,1612,1513,1427$, 1247, 1112, 702; ${ }^{1} \mathrm{H}$ NMR (300 MHz, $\left.\mathrm{CDCl}_{3}\right)$ 7.71-7.65 (4H, m), 7.45-7.35 (6H, m), $7.24(2 \mathrm{H}, \mathrm{d}, \mathrm{J}=5.4 \mathrm{~Hz}), 6.84(2 \mathrm{H}, \mathrm{d}, \mathrm{J}=5.4 \mathrm{~Hz}), 4.49-4.45(3 \mathrm{H}, \mathrm{m}), 3.80-3.66(4 \mathrm{H}$, m), $1.20(6 \mathrm{H}, \mathrm{s}), 1.06(9 \mathrm{H}, \mathrm{s}) ;{ }^{13} \mathrm{C}$ NMR (100 MHz) 159.2, 135.8, 135.7, 133.3, 133.1, $130.8,130.7,130.0,129.3,128.0,113.9,91.8,78.3,78.0,73.1,67.9,63.9,63.5,55.5$, 32.5, 26.9, 26.1, 19.5; m/z (ESIMS) calculated for $\mathrm{C}_{32} \mathrm{H}_{40} \mathrm{O}_{4} \mathrm{SiNa}[\mathrm{MNa}]^{+}$539.26, found: 539.4 .

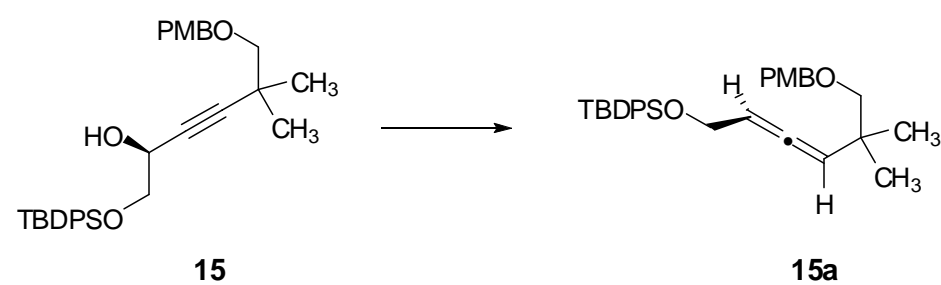

A solution of $\mathrm{PPh}_{3}(6.9 \mathrm{~g}, 26.3 \mathrm{mmol})$ in $100 \mathrm{~mL}$ THF was cooled to $-15^{\circ} \mathrm{C}$ and was added DIAD $(5.17 \mathrm{ml}, 26.3 \mathrm{mmol})$. The mixture was stirred for $10 \mathrm{~min}$ then a solution of alcohol 15 (9.05 g, $17.5 \mathrm{mmol})$ in $80 \mathrm{~mL} \mathrm{THF}$ was added. After $10 \mathrm{~min}$, NBSH (5.7 $\mathrm{g}, 26.3 \mathrm{mmol}$ ) in $100 \mathrm{~mL}$ THF was added at $-15^{\circ} \mathrm{C}$. Stirring continued after warming to $\mathrm{rt}$ for $12 \mathrm{~h}$. The solvent was removed under vacuum and the crude was directly purified by FCC (silica gel, hexane/ethyl acetate 1:15) to afford allene (6.2 g, 70\%) as a colorless oil. $[\alpha]_{D}^{25}=-35.7\left(\mathrm{c}=1.82, \mathrm{CHCl}_{3}\right) ; \mathrm{IR} v_{\max }$ (neat) $/ \mathrm{cm}^{-1} 3070,2958$, 2930, 1962, 1612, 1513, 1112, 702; ${ }^{1} \mathrm{H}$ NMR (300 MHz, $\left.\mathrm{CDCl}_{3}\right)$ 7.73-7.67 (4H, m), 7.42-7.26 (6H, m), $7.23(2 \mathrm{H}, \mathrm{d}, \mathrm{J}=5.7 \mathrm{~Hz}), 6.86(2 \mathrm{H}, \mathrm{d}, \mathrm{J}=5.7 \mathrm{~Hz}), 5.35-5.22(2 \mathrm{H}$, m), 4.43( 2H, s), $4.20(2 \mathrm{H}, \mathrm{dd}, \mathrm{J}=2.7,6.0), 3.80(3 \mathrm{H}, \mathrm{s}), 3.15(2 \mathrm{H}, \mathrm{s}) 1.04(9 \mathrm{H}, \mathrm{s})$, $1.02(3 \mathrm{H}, \mathrm{s}), 1.01(3 \mathrm{H}, \mathrm{s}) ; \mathrm{m} / z$ (ESIMS) calculated for $\mathrm{C}_{32} \mathrm{H}_{40} \mathrm{O}_{3} \mathrm{SiNa}[\mathrm{MNa}]^{+}$523.26, found: 523.3 . 


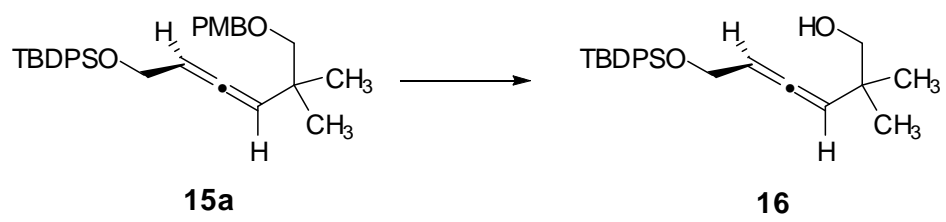

To a solution of allene $(6.25 \mathrm{~g}, 12.4)$ in $\mathrm{CH}_{2} \mathrm{Cl}_{2}(80 \mathrm{~mL})$ was added buffer $(8 \mathrm{~mL}, \mathrm{pH}=$ 7.40) and cooled to $0{ }^{\circ} \mathrm{C}$. DDQ was added to the mixture and stirred for $30 \mathrm{~min}$. The reaction mixture was quenched with $\mathrm{NaHCO}_{3}$, diluted with $\mathrm{H}_{2} \mathrm{O}$, extracted with $\mathrm{CH}_{2} \mathrm{Cl}_{2}$ and dried over $\mathrm{Na}_{2} \mathrm{SO}_{4}$. Solvent was evaporated and the residue was purified by FCC using hexane/ethyl acetate (20:1) as eluent to furnish alcohol 16 (4.65 g, 98\%) as a colorless oil. IR $v_{\max }\left(\right.$ neat) $/ \mathrm{cm}^{-1} 3419,3071,2959,2930,2858,1962,1471$, 1427, 1112, 702; ${ }^{1} \mathrm{H}$ NMR (400 MHz, $\left.\mathrm{CDCl}_{3}\right)$ 7.70-7.68 (4H, m), 7.45-7.36 (6H, m), 5.36-5.31 (1H, m), 5.17-5.14 (1H, m), 4.20-4.17 (2H, m), $3.42(1 \mathrm{H}, \mathrm{d}, \mathrm{J}=10.8 \mathrm{~Hz})$, $3.31(1 \mathrm{H}, \mathrm{d}, \mathrm{J}=10.8 \mathrm{~Hz}), 1.05(9 \mathrm{H}, \mathrm{s}), 1.01(6 \mathrm{H}, \mathrm{s}) ;{ }^{13} \mathrm{C} \mathrm{NMR}(100 \mathrm{MHz}) 201.9$, $135.7,133.6,129.9,127.9,100.9,93.7,71.5,62.0,37.7,26.9,25.1,24.9,19.4 ; \mathrm{m} / \mathrm{z}$ (ESIMS) calculated for $\mathrm{C}_{24} \mathrm{H}_{32} \mathrm{O}_{3} 2 \mathrm{iNa}[\mathrm{MNa}]^{+} 403.2$, found: 403.3 .

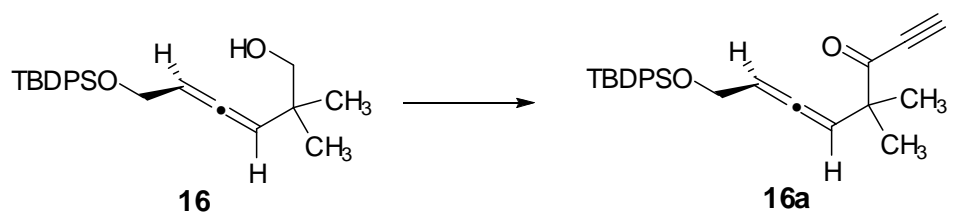

A solution of alcohol $(6.4 \mathrm{~g}, 16.8 \mathrm{mmol})$ in $\mathrm{CH}_{2} \mathrm{Cl}_{2}(100 \mathrm{~mL})$ was treated with DessMartin Periodinone at room temperature, After stirring for $2 \mathrm{~h}$, the mixture was quenched with a 2:1 (v/v) mixture of saturated $\mathrm{NaHCO}_{3}$ and saturated $\mathrm{Na}_{2} \mathrm{~S}_{2} \mathrm{O}_{3}$ and extracted with $\mathrm{CH}_{2} \mathrm{Cl}_{2}$. The combined organic extracts were dried over $\mathrm{Na}_{2} \mathrm{SO}_{4}$ and solvent was removed in vacuo. The crude was passed through a pad of silica gel and used for next step without further purification.

To the solution of aldehyde $(5.2 \mathrm{~g}, 13.7 \mathrm{mmol})$ in THF $(80 \mathrm{~mL})$ at $-78{ }^{\circ} \mathrm{C}$ was added the ethynyl magnesium bromide solution slowly. After stirring for $5 \mathrm{~min}$, the reaction mixture was placed in refrigerator for $12 \mathrm{~h}$. The mixture was quenched with saturated $\mathrm{NH}_{4} \mathrm{Cl}$ at cold temperature, extracted with $\mathrm{CH}_{2} \mathrm{Cl}_{2}$ and then dried over $\mathrm{Na}_{2} \mathrm{SO}_{4}$. The crude was passed through a pad of silica gel and used for next step without further purification. Diastreomeric ratio was determined by H NMR as 1:1. The crude alcohol was dissolved in $\mathrm{CH}_{2} \mathrm{Cl}_{2}(100 \mathrm{~mL})$ and treated with Dess-Martin periodinone $(8.2 \mathrm{~g}$, $19.3 \mathrm{mmol}$ ) at room temperature. The mixture was stirred for $30 \mathrm{~min}$ and then 
quenched with a 2:1 (v/v) mixture of saturated $\mathrm{NaHCO}_{3}$ and saturated $\mathrm{Na}_{2} \mathrm{~S}_{2} \mathrm{O}_{3}$. The aqueous phase was extracted with $\mathrm{CH}_{2} \mathrm{Cl}_{2}$ and dried over $\mathrm{Na}_{2} \mathrm{SO}_{4}$. Evaporation of the solvent and then purification by FCC using hexane/ethyl acetate (20:1) as eluent afforded ketone $\left(5.4 \mathrm{~g}, 80 \%\right.$ over three steps) as a colorless oil. IR $v_{\max }($ neat $) / \mathrm{cm}^{-1}$ 3269, 3071, 2961, 2931, 2091, 1964, 1680, 1464, 1427, 1112, 702; ${ }^{1} \mathrm{H}$ NMR (400 $\left.\mathrm{MHz}, \mathrm{CDCl}_{3}\right)$ 7.68-7.66 (4H, m), 7.42-7.35 (6H, m), 5.48-5.43 (1H, m), 5.35-5.32 $(1 \mathrm{H}, \mathrm{m}), 4.24-4.22(2 \mathrm{H}, \mathrm{m}), 3.13(1 \mathrm{H}, \mathrm{s}), 1.27(6 \mathrm{H}, \mathrm{s}), 1.04(9 \mathrm{H}, \mathrm{s}) ;{ }^{13} \mathrm{C}$ NMR $(100$ MHz) 203.3, 190.3, 135.7, 133.7, 129.9, 127.9, 97.6, 95.2, 80.8, 79.8, 61.9, 48.5, 27.0, 24.1, 23.8, 19.4; m/z (ESIMS) calculated for $\mathrm{C}_{26} \mathrm{H}_{30} \mathrm{O}_{2} \mathrm{SiNa}[\mathrm{MNa}]^{+} 425.19$, found: 425.2 .

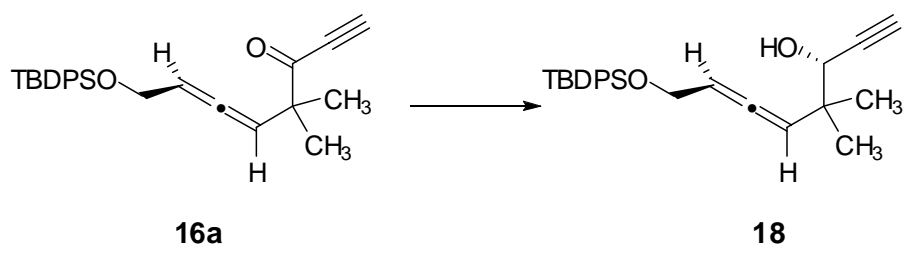

A solution of S-(CBS) $(2.6 \mathrm{~g}, 9.32 \mathrm{mmol})$ in THF $(40 \mathrm{~mL})$ at $-30{ }^{\circ} \mathrm{C}$ was treated with $\mathrm{BH}_{3} \cdot \mathrm{SMe}_{2}$ (4.66 mL, 9.32mmol, 2.0 M in THF). After stirring for $15 \mathrm{~min}$, a solution of ketone $(3.57 \mathrm{~g}, 8.80 \mathrm{mmol})$ in THF was added over the course of $10 \mathrm{~min}$. The reaction mixture was stirred for $1 \mathrm{~h}$ and quenched with $\mathrm{MeOH}$. The mixture was concentrated down and purified by FCC using hexane/ethyl acetate $(1: 30)$ as eluent to furnish alcohol $(3.20 \mathrm{~g}, 90 \%$, dr: $10: 1)$ as a colorless oil. $[\alpha]^{25}=-83.5(\mathrm{c}=1.70$, $\mathrm{CHCl}_{3}$ ); IR $v_{\max }($ neat $) / \mathrm{cm}^{-1} 3303,3071,2961,2930,1953,1472,1427,1112,701 ;{ }^{1} \mathrm{H}$ NMR (400 MHz, $\left.\mathrm{CDCl}_{3}\right)$ 7.70-7.67 (m, 4H), 7.44-7.36 (m, 6H), 5.38 (dd, 1H, J=6.0, $12.0 \mathrm{~Hz}), 5.27(\mathrm{~m}, 1 \mathrm{H}), 4.21(\mathrm{~m}, 2 \mathrm{H}), 4.06(\mathrm{dd}, 1 \mathrm{H}, \mathrm{J}=2.4,6.4 \mathrm{~Hz}), 2.41(\mathrm{~d}, 1 \mathrm{H}, \mathrm{J}=2.0$ $\mathrm{Hz}), 2.16(\mathrm{~d}, 1 \mathrm{H}, \mathrm{J}=6.8 \mathrm{~Hz}), 1.11(\mathrm{~s}, 3 \mathrm{H}), 1.11(\mathrm{~s}, 3 \mathrm{H}), 1.05(\mathrm{~s}, 9 \mathrm{H}) ;{ }^{13} \mathrm{C}$ NMR $(100$ MHz) 202.8, 135.6, 133.6, 133.5, 129.7, 127.7, 98.9, 93.9, 74.1, 70.2, 62.1, 40.3, 26.8, 24.1, 23.3, 19.2; m/z (ESIMS) calculated for $\mathrm{C}_{26} \mathrm{H}_{32} \mathrm{O}_{2} \mathrm{SiNa}[\mathrm{MNa}]^{+} 427.21$, found: 427.2 .

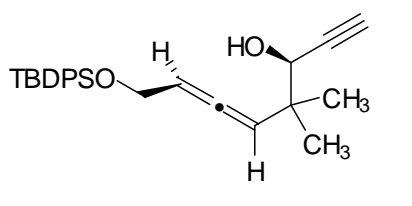

18

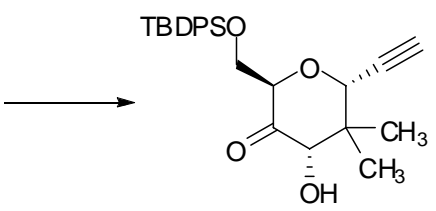

22 
To a solution of allene $(3.0 \mathrm{~g}, 7.42 \mathrm{mmol})$ in $\mathrm{CHCl}_{3}(100 \mathrm{~mL})$ was added DMDO in $\mathrm{CHCl}_{3}(115 \mathrm{~mL}, 22 \mathrm{mmol})$ slowly at $0{ }^{\circ} \mathrm{C}$. The mixture was stirred for $40 \mathrm{~min}$ at $0{ }^{\circ} \mathrm{C}$, followed by addition of $\mathrm{MeOH}(100 \mathrm{ml})$. After stirring for $12 \mathrm{~h}$ at room temperature the mixture was concentrated down in vacuo. Purification by FCC using hexane/ethyl acetate $(25: 1)$ as eluent provided ketone $22(2.33 \mathrm{~g}, 72 \%)$ as a colorless oil. The ratio was $8: 1$, as determined by NMR. $[\alpha]^{25}=+6.76\left(\mathrm{c}=1.05, \mathrm{CHCl}_{3}\right) ; \mathrm{IR} v_{\max }($ neat $) / \mathrm{cm}^{-1}$ 3500, 3285, 3071, 2962, 2931, 1732, 1471, 1428, 1113, 701; ${ }^{1} \mathrm{H}$ NMR (400 MHz, $\left.\mathrm{CDCl}_{3}\right)$ 7.70-7.56 (4H, m), 7.48-7.36 (6H, m), $5.16(1 \mathrm{H}, \mathrm{d}, \mathrm{J}=2.4 \mathrm{~Hz}), 4.26(2 \mathrm{H}, \mathrm{s})$, $4.0=5(1 \mathrm{H}, \mathrm{dd}, \mathrm{J}=11.6,3.6 \mathrm{~Hz}), 3.90(1 \mathrm{H}, \mathrm{dd}, \mathrm{J}=11.6,3.6 \mathrm{~Hz}), 3.5(1 \mathrm{H}, \mathrm{brs}), 2.57$ (1H, d, J2.4 Hz), 1.05 (9H, s), 1.04 (3H, s), 1.01 (3H, s); ${ }^{13} \mathrm{C}$ NMR (100 MHz) 208.6, 161.9, 135.75., 13c cd26, 135.0, 132.0, 130.1, 129.6, 128.0, 127.7, 81.5, 81.1, 79.1, $75.2,73.1,66.0,44.4,26.8: 6.6,23.2,19.1,14.9 ; \mathrm{m} / \mathrm{z}$ (ESIMS) calculated for $\mathrm{C}_{26} \mathrm{H}_{34} \mathrm{O}_{4} \mathrm{SiNa}[\mathrm{MNa}]^{+} 459.20$, found: 459.2.

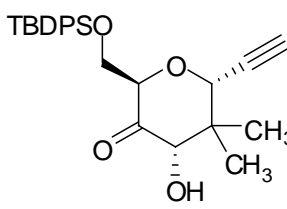

22

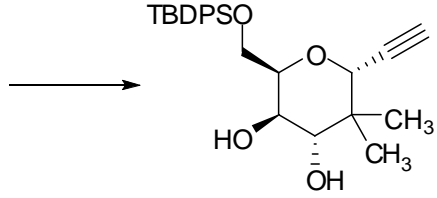

23

To a solution of ketone $22(2.03 \mathrm{~g}, 4.6 \mathrm{mmol})$ and $\mathrm{Me}_{4} \mathrm{NBH}(\mathrm{OAc})_{3}(6.12 \mathrm{~g}, 23.3$ $\mathrm{mmol})$, in $\mathrm{CH}_{3} \mathrm{CN}(40 \mathrm{~mL})$ at $-40{ }^{\circ} \mathrm{C}$ was added acetic acid $(10.0 \mathrm{~mL})$. After $5 \mathrm{~min}$, the reaction mixture was warmed to $-20{ }^{\circ} \mathrm{C}$ and kept at $-20{ }^{\circ} \mathrm{C}$ for $48 \mathrm{~h}$. The mixture was quenched with saturated $\mathrm{NaHCO}_{3}$ at cold temperature, extracted with $\mathrm{CH}_{2} \mathrm{Cl}_{2}$ and dried over $\mathrm{Na}_{2} \mathrm{SO}_{4}$. Solvent was removed in vacuo and then the crude was purified by FCC using hexane/ethyl acetate (1:2) as eluent to give diol $22(1.50 \mathrm{~g}, 74 \%)$ as a white foam. $[\alpha]^{25}=+25.0\left(\mathrm{c}=1.00, \mathrm{CHCl}_{3}\right)$; IR $v_{\max }($ neat $) / \mathrm{cm}^{-1} 3436,3304,3071$, 2960, 2931, 1723, 1471, 1427, 1113, 702; ${ }^{1} \mathrm{H}$ NMR (400 MHz, $\left.\mathrm{CDCl}_{3}\right)$ 7.72-7.69 (4H, m), 7.44-7.39 (6H, m), $4.30(1 \mathrm{H}, \mathrm{d}, \mathrm{J}=2.4 \mathrm{~Hz}), 4.2(1 \mathrm{H}, \mathrm{q}, \mathrm{J}=5.2 \mathrm{~Hz}), 4.07(1 \mathrm{H}, \mathrm{dd}$, $\mathrm{J}=11.2,4.8 \mathrm{~Hz}), 4.00-3.92(2 \mathrm{H}, \mathrm{m}), 3.55(1 \mathrm{H}, \mathrm{d}, \mathrm{J}=8 \mathrm{~Hz}), 2.48(1 \mathrm{H}, \mathrm{d}, \mathrm{J}=2.4 \mathrm{~Hz})$, $1.10(6 \mathrm{H}, \mathrm{s}), 1.07(9 \mathrm{H}, \mathrm{s}) ;{ }^{13} \mathrm{C}$ NMR $(75 \mathrm{MHz}) 135.8,132.6,130.1,128.0,80.5,76.7$, $75.2,73.7,71.4,70.7,63.2,56.8,39.9,27.2,24.3,19.5 ; \mathrm{m} / \mathrm{z}$ (ESIMS) calculated for $\mathrm{C}_{32} \mathrm{H}_{40} \mathrm{O}_{3} \mathrm{SiNa}[\mathrm{MNa}]^{+}$461.21, found: 461.3. 


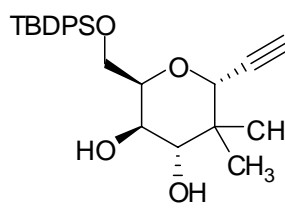

23

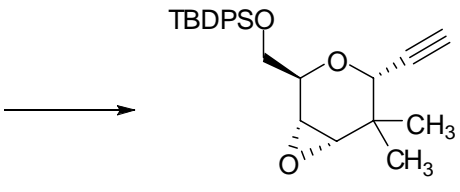

24

To a solution of diol $23(1.14 \mathrm{~g}, 2.6 \mathrm{mmol})$ in THF $(20 \mathrm{~mL}$, containing trace amount of water) at $0{ }^{\circ} \mathrm{C}$ was added $\mathrm{NaH}(832 \mathrm{mg}, 10.4 \mathrm{mmol}, 60 \%$ dispersion in mineral oil) and the mixture was stirred for $10 \mathrm{~min}$. To this was added a solution of $\mathrm{TsCl}$ in $6 \mathrm{~mL}$ THF and $200 \mu \mathrm{H}_{2} \mathrm{O}$. After stirring for $30 \mathrm{~min}$, the mixture was quenched with saturated $\mathrm{NH}_{4} \mathrm{Cl}$, extracted with $\mathrm{CH}_{2} \mathrm{Cl}_{2}$ and dried over $\mathrm{Na}_{2} \mathrm{SO}_{4}$. Solvent was removed and then the crude was purified by FCC using hexane/ethyl acetate (20:1) as eluent to furnish epoxide $24(760 \mathrm{mg}, 70 \%)$ as a colorless oil. $[\alpha]^{25}=-8.9\left(\mathrm{c}=1.23, \mathrm{CHCl}_{3}\right)$; IR $v_{\max }($ neat $) / \mathrm{cm}^{-1} 3285,3071,2960,2930,1471,1427,1113,702 ;{ }^{1} \mathrm{H}$ NMR (400 $\left.\mathrm{MHz}, \mathrm{CDCl}_{3}\right)$ 7.71-7.68 (4H, m), 7.50-7.40 (6H, m), $4.26(1 \mathrm{H}, \mathrm{t}, \mathrm{J}=4.4 \mathrm{~Hz}), 4.20$ $(1 \mathrm{H}, 2.4 \mathrm{~Hz}), 3.95-3.87(1 \mathrm{H}, \mathrm{m}), 3.38(1 \mathrm{H}, \mathrm{d}, \mathrm{J}=4.0 \mathrm{~Hz}), 3.00(1 \mathrm{H}, \mathrm{d}, \mathrm{J}=4.0 \mathrm{~Hz}), 2.51$ $(1 \mathrm{H}, \mathrm{d}, \mathrm{J}=2.4 \mathrm{~Hz}), 1.24(3 \mathrm{H}, \mathrm{s}), 1.18(3 \mathrm{H}, \mathrm{s}), 1.09(9 \mathrm{H}, \mathrm{s}) ;{ }^{13} \mathrm{C}$ NMR $(100 \mathrm{MHz})$ 135.6, 133.1, 129.9, 127.8, 80.1, 75.7, 70.7, 70.2, 64.9, 58.4, 53.1, 33.4, 26.8, 24.2, 21.6, 19.2; $\mathrm{m} / z$ (ESIMS) calculated for $\mathrm{C}_{26} \mathrm{H}_{32} \mathrm{O}_{3} \mathrm{Si} \mathrm{Na}[\mathrm{MNa}]^{+} 443.20$, found: 443.3.

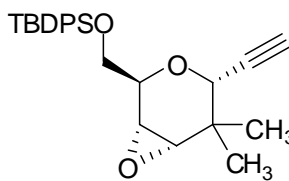

24

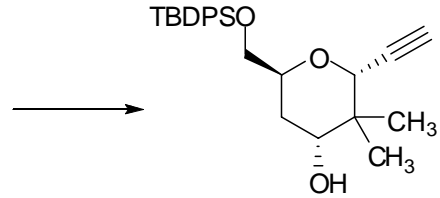

$24 a$

To a solution of epoxide $24(0.61 \mathrm{mg}, 1.45 \mathrm{mmol})$ in $\mathrm{Et}_{2} \mathrm{O}(10 \mathrm{~mL})$ at $0{ }^{\circ} \mathrm{C}$ was added DIBAL (4.35 mL, $4.35 \mathrm{mmol}, 1.0 \mathrm{M}$ in hexane) at one portion. After $10 \mathrm{~min}$, the reaction mixture was quenched with saturated Rochelle's salt and diluted with $\mathrm{Et}_{2} \mathrm{O}$. The resulting biphasic solution was stirred for $1 \mathrm{~h}$. The layers were separated, and then the aqueous layer was extracted with $\mathrm{Et}_{2} \mathrm{O}$ and dried over $\mathrm{Na}_{2} \mathrm{SO}_{4}$. Solvent was concentrated in vacuo and the crude was purified by FCC using hexane/ethyl acetate $(10: 1)$ as eluent to afford alcohol $(489 \mathrm{mg}, 80 \%)$ as a colorless oil. $[\alpha]^{25} \mathrm{D}=+2.44(\mathrm{c}=$ 0.41, $\mathrm{CHCl}_{3}$ ); IR $v_{\max }\left(\right.$ neat) $/ \mathrm{cm}^{-1} 3454,3285,3070,2957,2930,1472,1427,1112$, 702; ${ }^{1} \mathrm{H}$ NMR (400 MHz, $\left.\mathrm{CDCl}_{3}\right)$ 7.69-7.67 (4H, m), 7.41-7.38 (6H, m), 4.40-4.20 $(2 \mathrm{H}, \mathrm{m}), 3.75(2 \mathrm{H}, \mathrm{d}, \mathrm{J}=4.8 \mathrm{~Hz}), 2.60-2.59(1 \mathrm{H}, \mathrm{m}), 2.38(1 \mathrm{H}, \mathrm{d}, \mathrm{J}=8.4 \mathrm{~Hz}), 2.04-$ $1.97(1 \mathrm{H}, \mathrm{m}), 1.71-1.66(1 \mathrm{H}, \mathrm{m}) ; \mathrm{m} / z$ (ESIMS) calculated for $\mathrm{C}_{26} \mathrm{H}_{34} \mathrm{O}_{3} \mathrm{SiNa}[\mathrm{MNa}]^{+}$ 
445.22, found: 445.3 .

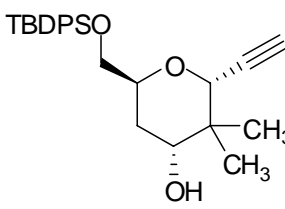

24a

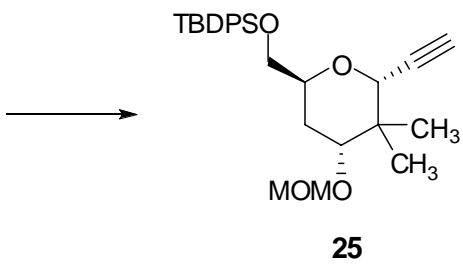

To a solution of alcohol $(360 \mathrm{mg}, 0.85 \mathrm{mmol})$ in DMF $(10 \mathrm{~mL})$ at $0{ }^{\circ} \mathrm{C}$ was added Hunig's base $(1.5 \mathrm{~mL}, 8.53 \mathrm{mmol})$ followed by $\mathrm{MOMCl}(0.65 \mathrm{~mL}, 8.53 \mathrm{mmol})$. The reaction mixture was stirred for $24 \mathrm{~h}$ at room temperature, and then quenched with saturated $\mathrm{NH}_{4} \mathrm{Cl}$ solution. The resulting mixture was extracted with $\mathrm{CH}_{2} \mathrm{Cl}_{2}$. The organic layers were washed with $\mathrm{H}_{2} \mathrm{O}$, dried over $\mathrm{Na}_{2} \mathrm{SO}_{4}$ and concentrated under reduced pressure under reduced pressure in vacuo. The crude was purified by FCC using ethyl acetate/hexane (1:20) to give product $\mathbf{2 5}$ as colorless oil (390 $\mathbf{m g}, \mathbf{9 7 \%}$ ). $[\alpha]^{25}=+0.91\left(\mathrm{c}=1.10, \mathrm{CHCl}_{3}\right) ; \mathrm{IR} v_{\max }($ neat $) / \mathrm{cm}^{-1} 3288,3071,2949,2930,1472$, 1428, 1042, 702; ${ }^{1} \mathrm{H}$ NMR (400 MHz, $\mathrm{CDCl}_{3}$ ) 7.70-7.67 (4H, m), 7.41-7.39 (6H, m), $4.70(1 \mathrm{H}, \mathrm{d}, \mathrm{J}=6.8 \mathrm{~Hz}), 4.60(1 \mathrm{H}, \mathrm{d}, \mathrm{J}=7.2 \mathrm{~Hz}), 4.22-4.18(2 \mathrm{H}, \mathrm{m}), 3.74(2 \mathrm{H}, \mathrm{J}=9.2$ $\mathrm{Hz}), 3.55-3.52(1 \mathrm{H}, \mathrm{m}), 3.38(3 \mathrm{H}, \mathrm{s}), 1.94-1.89(2 \mathrm{H}, \mathrm{m}), 1.10(3 \mathrm{H}, \mathrm{s}), 1.07(9 \mathrm{H}, \mathrm{s})$, $1.06(3 \mathrm{H}, \mathrm{s}) ;{ }^{13} \mathrm{C}$ NMR (100 MHz) 135.7, 133.4, 129.7, 127.7, 95.9, 81.3, 77.8, 74.0, $71.7,70.4,65.9,55.5,37.9,28.3,26.8,24.7,19.2,18.8 ; \mathrm{m} / \mathrm{z}$ (ESIMS) calculated for $\mathrm{C}_{28} \mathrm{H}_{38} \mathrm{O}_{4} \mathrm{SiNa}[\mathrm{MNa}]^{+}$489.24, found: 489.3.

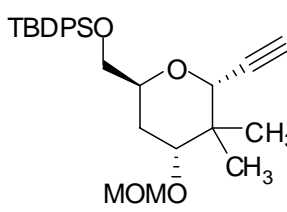

25

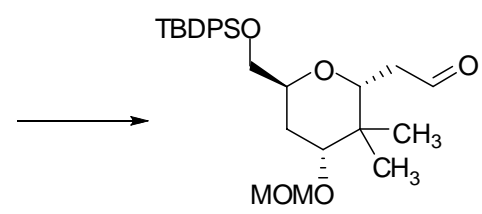

26

To the 2-methyl-2-butene (2.30 $\mathrm{mL}$ of $2 \mathrm{M}$ solution in THF, $4.60 \mathrm{mmol})$ cooled to 0 ${ }^{\circ} \mathrm{C}$ was added $\mathrm{BH}_{3} \cdot \mathrm{SMe}_{2}(1.15 \mathrm{~mL}$ of $1 \mathrm{M}$ solution in THF, $2.30 \mathrm{mmol})$ dropwise. The ice-bath was removed and the mixture was stirred for $1 \mathrm{~h}$. The reaction mixture was cooled to $0{ }^{\circ} \mathrm{C}$, to which was added a solution of alkyne 25 (356 mg, $\left.0.76 \mathrm{mmol}\right)$ in THF slowly. The mixture was stirred for $30 \mathrm{~min}$ at room temperature and cooled back to $0{ }^{\circ} \mathrm{C}$. The reaction mixture was quenched with a precooled solution of $4 \mathrm{~mL}$ of $3 \mathrm{~N}$ $\mathrm{NaOH}$ and $1.4 \mathrm{~mL}$ of $30 \% \mathrm{H}_{2} \mathrm{O}_{2}$ dropwise. The resulting mixture was stirred for 30 min at room temperature, then and extracted with $\mathrm{CH}_{2} \mathrm{Cl}_{2}$. The organic layers were 
dried over $\mathrm{Na}_{2} \mathrm{SO}_{4}$ and concentrated under reduced pressure under reduced pressure in vacuo. The crude was purified by FCC using hexane/ethyl acetate (15:1) to furnish aldehyde $26(282 \mathrm{mg}, 76 \%)$ as a colorless oil. $[\alpha]^{25}=+7.14\left(\mathrm{c}=0.84, \mathrm{CHCl}_{3}\right)$; IR $v_{\max }($ neat $) / \mathrm{cm}^{-1} 3071,2949,2931,2888,2857,1728,1472,1428,1112,702 ;{ }^{1} \mathrm{H}$ NMR $\left(400 \mathrm{MHz} \mathrm{CDCl}_{3}\right) 9.72(1 \mathrm{H}, \mathrm{dd}, \mathrm{J}=1.6,3.6 \mathrm{~Hz}), 4.68(1 \mathrm{H}, \mathrm{d}, \mathrm{J}=5.2 \mathrm{~Hz}), 4.59(1 \mathrm{H}, \mathrm{d}$, $\mathrm{J}=5.2 \mathrm{~Hz}), 4.04-3.96(2 \mathrm{H}, \mathrm{m}), 3.78-3.67(2 \mathrm{H}, \mathrm{m}), 2.85-2.77(1 \mathrm{H}, \mathrm{m}), 2.44(1 \mathrm{H}, \mathrm{qd}, \mathrm{J}=$ 1, 17.6 Hz), 1.94-1.88 (1H, m), 1.81-1.74 (1H, m); ${ }^{13} \mathrm{C}$ NMR (100 MHz) 202.5, 135.6, 133.3, 129.7, 127.7, 95.9, 78.2, 75.0, 70.0, 65.5, 55.6, 43.4, 37.4, 28.2, 26.8, 24.4, 19.1, 17.0; $\mathrm{m} / z$ (ESIMS) calculated for $\mathrm{C}_{28} \mathrm{H}_{40} \mathrm{O}_{5} \mathrm{SiNa}[\mathrm{MNa}]^{+}$507.25, found: 507.3.
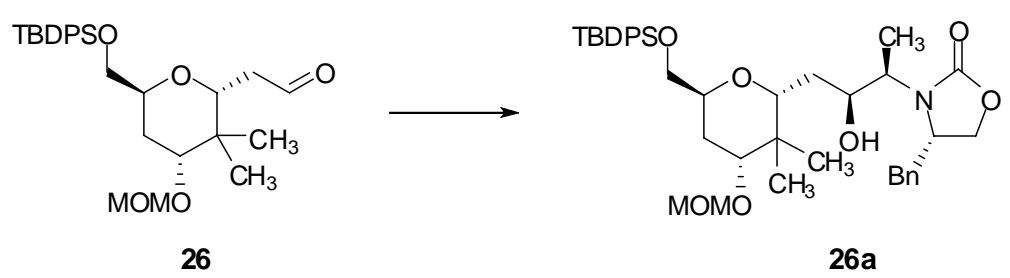

To a solution of (R)-Evan's oxazolidone 27 (172 $\mathrm{mg}, 0.738 \mathrm{mmol})$ in $3.0 \mathrm{~mL} \mathrm{CH}_{2} \mathrm{Cl}_{2}$ at $-78{ }^{\circ} \mathrm{C}$ was added $\mathrm{Bu}_{2} \mathrm{BOTf}$ in $\mathrm{CH}_{2} \mathrm{Cl}_{2}(0.80 \mathrm{~mL}, 1.0 \mathrm{M})$ dropwise followed with $125 \mathrm{mg} \mathrm{NEt}_{3}$. The mixture was allowed to warm to $0{ }^{\circ} \mathrm{C}$ and stirred for $30 \mathrm{~min}$, and then cooled again to $-78{ }^{\circ} \mathrm{C}$. Aldehyde $26(300 \mathrm{mg}, 0.620 \mathrm{mmol})$ in $2.0 \mathrm{~mL} \mathrm{CH} \mathrm{Cl}_{2}$ was added into the mixture. The reaction mixture was stirred and allowed to warm to $0{ }^{\circ} \mathrm{C}$ slowly over $1.5 \mathrm{~h}$. $1 \mathrm{~mL}$ phosphate buffer solution was added to quench the reaction followed with the addition of $1 \mathrm{~mL} \mathrm{MeOH}$ and $0.5 \mathrm{~mL} \mathrm{H}_{2} \mathrm{O}_{2}$. The resulting mixture was stirred at $0{ }^{\circ} \mathrm{C}$ for $10 \mathrm{~min}$, diluted with distilled water and extracted with $\mathrm{CH}_{2} \mathrm{Cl}_{2}$. The combined organic extracts were dried over $\mathrm{Na}_{2} \mathrm{SO}_{4}$ and concentrated under reduced pressure. The residue was purified by FCC (silica gel, ethyl acetate/hexane $1: 3)$ to give $417 \mathrm{mg}$ product $(93 \%)$ as white foam. $[\alpha]^{25}{ }_{\mathrm{D}}=-18.4$ $\left(\mathrm{CHCl}_{3}, \mathrm{c}=1.41\right) ;{ }^{1} \mathrm{H} \mathrm{NMR}\left(400 \mathrm{MHz}, \mathrm{CDCl}_{3}\right) 7.68(\mathrm{~m}, 4 \mathrm{H}), 7.41(\mathrm{~m}, 6 \mathrm{H}), 7.28(\mathrm{~m}$, $5 \mathrm{H}), 4.65(\mathrm{~d}, 1 \mathrm{H}, \mathrm{J}=6.8 \mathrm{~Hz}), 4.58(\mathrm{~m}, 1 \mathrm{H}), 4.55(\mathrm{~d}, 1 \mathrm{H}, \mathrm{J}=7.2 \mathrm{~Hz}), 4.13(\mathrm{~m}, 4 \mathrm{H})$, $3.99(\mathrm{t}, 1 \mathrm{H}, \mathrm{J}=8.4 \mathrm{~Hz}), 3.84(\mathrm{~m}, 2 \mathrm{H}), 3.61(\mathrm{dd}, 1 \mathrm{H}, \mathrm{J}=10.8,2.0 \mathrm{~Hz}), 3.57(\mathrm{dd}, 1 \mathrm{H}, \mathrm{J}=$ 10.8, 5.2 Hz), 3.40 (dd, 1H, J= 9.2, 5.2 Hz), 3.34 (s, 3H), 3.28 (dd, 1H, J=13.2, 2.8 $\mathrm{Hz}), 2.75(\mathrm{dd}, 1 \mathrm{H}, \mathrm{J}=13.2,10.0 \mathrm{~Hz}), 1.86(\mathrm{~m}, 1 \mathrm{H}), 1.78(\mathrm{~m}, 2 \mathrm{H}), 1.28$ (d, 3H, J= 7.2 $\mathrm{Hz}), 1.04$ (s, 9H) 0.95 (s, 3H), $0.93(\mathrm{~s}, 3 \mathrm{H}) ;{ }^{13} \mathrm{C} \mathrm{NMR}\left(100 \mathrm{MHz}, \mathrm{CDCl}_{3}\right)$ 175.6, $153.4,135.9,135.8,135.7,133.4,133.3,130.0,129.9,129.7,129.1,128.0,128.0$, $127.5,96.1,80.3$, 78.2, 73.0, 71.6, 66.2 , 64.5, 55.8, 43.5, 38.5, 38.0, 32.7, 28.1, 26.9, 
24.0, 19.3, 15.7, 11.5; IR $v \max$ (neat) / $\mathrm{cm}^{-1} 3481,2884,2860,1781,1697,1474$, 1428, 1386, 1210, 1110, 1040, 914; $\mathrm{m} / \mathrm{z}$ (ESIMS) calculated for $\mathrm{C}_{41} \mathrm{H}_{55} \mathrm{O}_{8} \mathrm{NSiNa}$ $[\mathrm{MNa}]^{+} 740.36$, found: 740.4 .

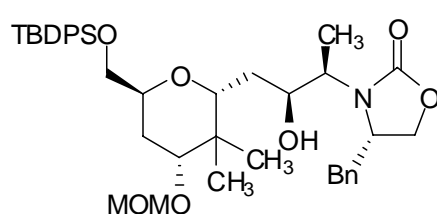

$26 a$

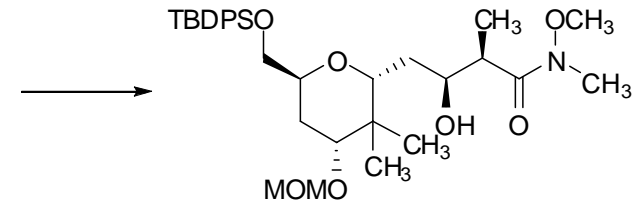

26b

To a suspension of $\mathrm{CH}_{3}\left(\mathrm{CH}_{3} \mathrm{O}\right) \mathrm{NH} \cdot \mathrm{HCl}(170 \mathrm{mg}, 1.73 \mathrm{mmol})$ in $3.0 \mathrm{~mL}$ THF at $0^{\circ} \mathrm{C}$ was added $\mathrm{AlMe}_{3}$ in toluene $(0.80 \mathrm{~mL}, 1.0 \mathrm{M})$ slowly. The mixture was allowed to warm to room temperature and stirred for $30 \mathrm{~min}$. The reaction was cooled again to 0 ${ }^{\circ} \mathrm{C}$ and the aldol product (410 mg, $0.572 \mathrm{mmol}$ ) in $3 \mathrm{~mL}$ THF was added. The ice bath was removed and the reaction mixture was stirred for $2 \mathrm{~h}$. Saturated Rochelle's salt solution was added to quench the reaction. After stirring for $30 \mathrm{~min}$, the mixture was diluted with distilled water and extracted with $\mathrm{CH}_{2} \mathrm{Cl}_{2}$. The combined organic extracts were dried over $\mathrm{Na}_{2} \mathrm{SO}_{4}$ and concentrated under reduced pressure. The residue was purified by FCC (silica gel, ethyl acetate/hexane 1:3) to give $331 \mathrm{mg}$ product (96\%) as white foam. $[\alpha]^{25}{ }_{\mathrm{D}}=+8.2\left(\mathrm{CHCl}_{3}, \mathrm{c}=0.85\right) ;{ }^{1} \mathrm{H} \mathrm{NMR}\left(400 \mathrm{MHz}, \mathrm{CDCl}_{3}\right) 7.69(\mathrm{~m}$, 4H), $7.42(\mathrm{~m}, 6 \mathrm{H}), 4.65(\mathrm{~d}, 1 \mathrm{H}, \mathrm{J}=6.8 \mathrm{~Hz}), 4.55(\mathrm{~d}, 1 \mathrm{H}, \mathrm{J}=6.8 \mathrm{~Hz}), 4.31(\mathrm{~d}, 1 \mathrm{H}, \mathrm{J}=$ $0.8 \mathrm{~Hz}) 3.92(\mathrm{~m}, 1 \mathrm{H}), 3.81(\mathrm{dd}, 1 \mathrm{H}, \mathrm{J}=8.0,10.8 \mathrm{~Hz}), 3.64(\mathrm{~s}, 3 \mathrm{H}), 3.57(\mathrm{dd}, 1 \mathrm{H}, \mathrm{J}=$ 5.2, $10.4 \mathrm{~Hz}$ ), 3.53 (dd, 1H, J=2.0, $10.8 \mathrm{~Hz}), 3.39$ (dd, 1H, J=4.8, 9.2 Hz), 3.34 (s, $3 \mathrm{H}), 3.17(\mathrm{~s}, 1 \mathrm{H}), 2.99(\mathrm{br}, 1 \mathrm{H}), 1.77(\mathrm{~m}, 3 \mathrm{H}), 1.62(\mathrm{~m}, 1 \mathrm{H}), 1.20(\mathrm{~d}, 3 \mathrm{H}, \mathrm{J}=6.8 \mathrm{~Hz})$, 1.06 (s, 9H), 0.92 (s, 3H), 0.91 (s, 3H); ${ }^{13} \mathrm{C}$ NMR (100 MHz, $\mathrm{CDCl}_{3}$ ) 177.1, 135.9, 135.8, 133.4, 130.0, 128.0, 128.0, 96.1, 79.9, 78.3, 73.5, 71.5, 64.4, 61.6, 55.7, 40.7, 38.4, 32.6, 28.1, 26.9, 24.1, 19.3, 15.6, 13.6; IR $v$ max (neat) $/ \mathrm{cm}^{-1} 3484,3072,3048$, 2880, 2852, 1659, 1471, 1428, 1389, 1112, 1040, 916; $\mathrm{m} / \mathrm{z}$ (ESIMS) calculated for $\mathrm{C}_{33} \mathrm{H}_{51} \mathrm{O}_{7} \mathrm{NSiNa}[\mathrm{MNa}]^{+}$624.33, found: 624.4.
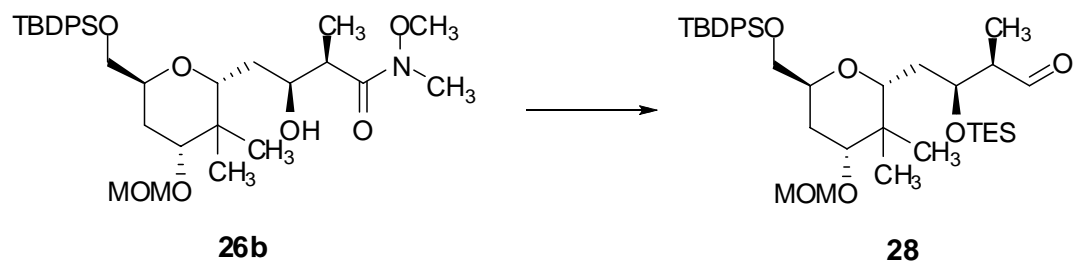

To a solution of the Weinreb amide $(296 \mathrm{mg}, 0.492 \mathrm{mmol})$ in $5.0 \mathrm{~mL} \mathrm{DMF}$ at room 
temperature was added imidazole (100 mg, $1.47 \mathrm{mmol})$ and TESCl (148 mg, 0.980 mmol). After stirring $1 \mathrm{~h}$ at room temperature, the reaction was quenched with water and extracted with $\mathrm{CH}_{2} \mathrm{Cl}_{2}$. The combined organic extracts were dried over $\mathrm{Na}_{2} \mathrm{SO}_{4}$ and concentrated under reduced pressure. The residue was filtered through a pad of silica gel with ethyl acetate/hexane 1:5. The filtrate was concentrated and dissolved in $5 \mathrm{~mL}$ THF. The solution was cooled to $-78{ }^{\circ} \mathrm{C}$ followed with the slow addition of DIBAL in hexane $(1.35 \mathrm{~mL}, 1.0 \mathrm{M})$. After stirring at $-78{ }^{\circ} \mathrm{C}$ for $30 \mathrm{~min}$, the reaction was quenched with saturated Rochelle's salt solution. The mixture was stirred at room temperature for $30 \mathrm{~min}$ and extracted with $\mathrm{CH}_{2} \mathrm{Cl}_{2}$. The combined organic extracts were dried over $\mathrm{Na}_{2} \mathrm{SO}_{4}$ and concentrated under reduced pressure. The residue was purified by FCC (silica gel, ethyl acetate/hexane 1:8) to give $292 \mathrm{mg}$ compound 27 (90\% over two steps) as colorless oil. $[\alpha]^{25}{ }_{\mathrm{D}}=-6.2\left(\mathrm{CHCl}_{3}, \mathrm{c}=0.65\right) ;{ }^{1} \mathrm{H}$ NMR (400 $\left.\mathrm{MHz}, \mathrm{CDCl}_{3}\right) 9.57(\mathrm{~s}, 1 \mathrm{H}), 7.68(\mathrm{~m}, 4 \mathrm{H}), 7.40(\mathrm{~m}, 6 \mathrm{H}), 4.70(\mathrm{~d}, 1 \mathrm{H}, \mathrm{J}=7.2 \mathrm{~Hz}), 4.60$ $(\mathrm{d}, 1 \mathrm{H}, \mathrm{J}=6.8 \mathrm{~Hz}), 4.52(\mathrm{~m}, 1 \mathrm{H}), 4.00(\mathrm{~m}, 1 \mathrm{H}), 3.75(\mathrm{dd}, 1 \mathrm{H}, \mathrm{J}=5.6,10.4 \mathrm{~Hz}), 3.66$ $(\mathrm{dd}, 1 \mathrm{H}, \mathrm{J}=5.2,10.4 \mathrm{~Hz}), 3.55(\mathrm{dd}, 1 \mathrm{H}, \mathrm{J}=4.0,8.0 \mathrm{~Hz}) 3.38(\mathrm{~s}, 3 \mathrm{H}), 3.36(\mathrm{~m}, 1 \mathrm{H})$, $2.50(\mathrm{ddd}, 1 \mathrm{H}, \mathrm{J}=2.8,6.8,14.0 \mathrm{~Hz}), 2.14(\mathrm{~m}, 1 \mathrm{H}), 1.83(\mathrm{~m}, 2 \mathrm{H}), 1.62(\mathrm{ddd}, 1 \mathrm{H}, \mathrm{J}=$ 2.4, 10.0, 14.0 Hz), 1.07 (s, 9H), 1.01(d, 3H, J=6.8 Hz), 0.99 (s, 3H), $0.92(\mathrm{~m}, 12 \mathrm{H})$, $0.56(\mathrm{~m}, 6 \mathrm{H}) ;{ }^{13} \mathrm{C}$ NMR $\left(100 \mathrm{MHz}, \mathrm{CDCl}_{3}\right)$ 204.9, 135.8, 135.8, 133.4, 130.0, 130.0, 128.0, 127.9, 96.3, 79.0, 76.4, 70.3, 68.5, 66.6, 55.7, 49.4, 37.9, 33.5, 28.9, 27.1, 24.8, 19.3, 17.1, 7.0, 6.2, 5.3 ; IR $v$ max (neat) $/ \mathrm{cm}^{-1}, 3068,3051,2877,1732,1471,1428$, $1389,1147,1105,1041,919 ; \mathrm{m} / z$ (ESIMS) calculated for $\mathrm{C}_{37} \mathrm{H}_{60} \mathrm{O}_{6} \mathrm{Si}_{2} \mathrm{Na}[\mathrm{MNa}]^{+}$ 679.38, found: 679.4 .

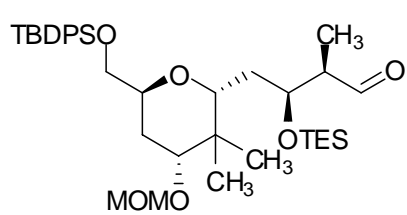

28

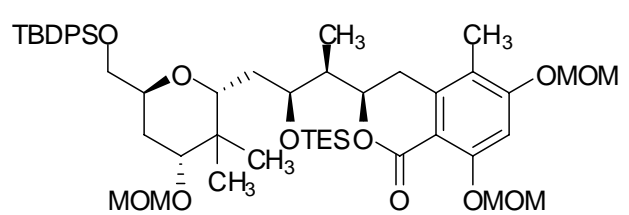

29

To a solution of compound $13(80 \mathrm{mg}, 0.282 \mathrm{mmol})$ in $10 \mathrm{~mL}$ THF at $-78{ }^{\circ} \mathrm{C}$ was added fresh made LDA $(0.61 \mathrm{~mL}, 0.46 \mathrm{M}, 0.281 \mathrm{mmol})$. The resulting deep red color solution was stirred at $-78{ }^{\circ} \mathrm{C}$ for $30 \mathrm{~min}$. The whole solution was transferred into the aldehyde 28 ( $123 \mathrm{mg}, 0.187 \mathrm{mmol}$ ) in $5 \mathrm{~mL}$ THF at $-100{ }^{\circ} \mathrm{C}$ by a syringe in dry ice bath. The reaction mixture was stirred at $-100{ }^{\circ} \mathrm{C}$ for $5 \mathrm{~min}$, quenched by $\mathrm{NH}_{4} \mathrm{Cl}$ solution and extracted with $\mathrm{CH}_{2} \mathrm{Cl}_{2}$. The combined organic extracts were dried over 
$\mathrm{Na}_{2} \mathrm{SO}_{4}$ and concentrated under reduced pressure. The residue was purified by FCC (silica gel, ethyl acetate/hexane 1:3) to give recovered aldehyde 27 (43 mg, 35\%) and $104 \mathrm{mg}$ product $\mathbf{2 9}(63 \%, 94 \%$ based on starting material, $81 \mathrm{mg}$ desired isomer $\mathbf{2 8}$, $23 \mathrm{mg}$ undesired isomer) as a colorless oil. $[\alpha]^{25}{ }_{\mathrm{D}}=+57.0\left(\mathrm{CHCl}_{3}, \mathrm{c}=1.28\right) ;{ }^{1} \mathrm{H} \mathrm{NMR}$ $\left(400 \mathrm{MHz}, \mathrm{CDCl}_{3}\right) 7.62(\mathrm{~m}, 4 \mathrm{H}), 7.28(\mathrm{~m}, 6 \mathrm{H}), 6.86(\mathrm{~s}, 1 \mathrm{H}) 5.26(\mathrm{~m}, 4 \mathrm{H}) 4.70(\mathrm{~d}, 1 \mathrm{H}$, $\mathrm{J}=6.8 \mathrm{~Hz}) 4.60(\mathrm{~d}, 1 \mathrm{H}, \mathrm{J}=6.8 \mathrm{~Hz}), 4.16(\mathrm{ddd}, 1 \mathrm{H}, \mathrm{J}=2.4,8.0,12.0 \mathrm{~Hz}), 4.06(\mathrm{~m}, 1 \mathrm{H})$, $3.94(\mathrm{~m}, 1 \mathrm{H}), 3.73(\mathrm{~m}, 2 \mathrm{H}), 3.63(\mathrm{dd}, 1 \mathrm{H}, \mathrm{J}=4.0,10.0 \mathrm{~Hz}), 3.56(\mathrm{~m}, 1 \mathrm{H}), 3.54(\mathrm{~s}, 3 \mathrm{H})$, 3.48 (s, 3H), 3.37 (s, 3H), $2.83(\mathrm{dd}, 1 \mathrm{H}, \mathrm{J}=2.0,16.0 \mathrm{~Hz}), 2.16(\mathrm{dd}, 1 \mathrm{H}, \mathrm{J}=12.0,16.0$ Hz), $2.04(\mathrm{~m}, 1 \mathrm{H}), 1.90(\mathrm{~s}, 1 \mathrm{H}), 1.83(\mathrm{~m}, 3 \mathrm{H}) 1.67(\mathrm{~m}, 2 \mathrm{H}), 1.04(\mathrm{~m}, 12 \mathrm{H}), 0.95$ (s, $3 \mathrm{H}), 0.87(\mathrm{~m}, 12 \mathrm{H}), 0.52(\mathrm{~m}, 6 \mathrm{H}) ;{ }^{13} \mathrm{C} \mathrm{NMR}\left(100 \mathrm{MHz}, \mathrm{CDCl}_{3}\right) 163.4,159.5,158.8$, 141.6, 135.9, 135.8, 133.5, 133.1, 129.9, 129.9, 127.9, 127.9, 117.4, 109.7, 102.1, 96.3, 96.1, 94.6, 79.2, 78.9, 77.4, 76.2, 70.7, 69.2, 68.2, 66.1, 56.8, 56.6, 55.7, 40.4, $38.1,33.4,30.0,28.6,27.1,25.8,24.4,19.3,15.5,11.2,9.0,7.2,5.6$; IR $v \max$ (neat) $/ \mathrm{cm}^{-1}, 3064,3044,1724,1589,1466,1152,1095,1046,1009 ; \mathrm{m} / \mathrm{z}$ (ESIMS) calculated for $\mathrm{C}_{50} \mathrm{H}_{76} \mathrm{O}_{11} \mathrm{Si}_{2} \mathrm{Na}[\mathrm{MNa}]^{+}$931.48, found: 931.6.

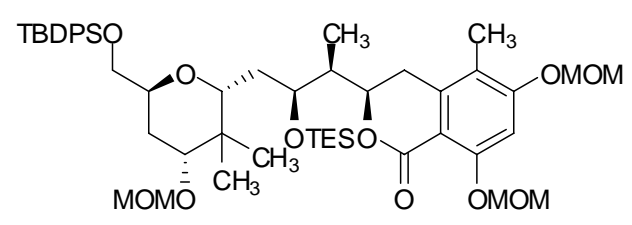

29

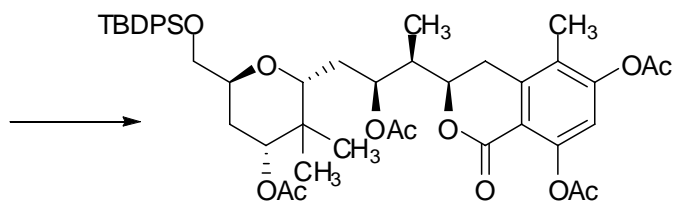

$29 a$

To a solution of compound 29 (45 mg, $0.050 \mathrm{mmol}$ ) in $2 \mathrm{~mL} \mathrm{CH}_{2} \mathrm{Cl}_{2}$ at $0{ }^{\circ} \mathrm{C}$ was added catechol borane bromide (200 mg, $1.00 \mathrm{mmol})$ in $2 \mathrm{~mL} \mathrm{CH}_{2} \mathrm{Cl}_{2}$. The mixture was stirred at $0{ }^{\circ} \mathrm{C}$ for $1 \mathrm{~h}$ and quenched with $\mathrm{THF} / \mathrm{NaHCO}_{3}$ solution. After dilution with distilled water and extraction with $\mathrm{CH}_{2} \mathrm{Cl}_{2}$, the combined organic extracts were dried over $\mathrm{Na}_{2} \mathrm{SO}_{4}$ and concentrated under reduced pressure. The residue was filtrated through a pad of silica gel with ethyl acetate/hexane 1:2. The filtrate was concentrated and dissolved in $1 \mathrm{~mL} \mathrm{CH} \mathrm{Cl}_{2}$. To the solution was added $1 \mathrm{~mL}$ pyridine and $0.5 \mathrm{~mL}$ acetic anhydride. The reaction mixture was stirred at room temperature for $30 \mathrm{~min}$ and then diluted with $\mathrm{CH}_{2} \mathrm{Cl}_{2}$, washed with $1 \mathrm{M} \mathrm{HCl}$. The organic layer was dried over $\mathrm{Na}_{2} \mathrm{SO}_{4}$ and concentrated under reduced pressure. The residue was purified by FCC (silica gel, ethyl acetate/hexane 1:4) to give $31 \mathrm{mg}$ product (75\%) as a colorless oil. $[\alpha]^{25}{ }_{\mathrm{D}}=+46.2\left(\mathrm{CHCl}_{3}, \mathrm{c}=0.52\right) ;{ }^{1} \mathrm{H} \mathrm{NMR}\left(400 \mathrm{MHz}, \mathrm{CDCl}_{3}\right) ; 7.65(\mathrm{~m}, 4 \mathrm{H}), 7.30(\mathrm{~m}$, $6 \mathrm{H}), 7.22(\mathrm{~m}, 1 \mathrm{H}), 5.00(\mathrm{dd}, 1 \mathrm{H}, \mathrm{J}=4.4,8.8 \mathrm{~Hz}), 4.15(\mathrm{~m}, 1 \mathrm{H}), 3.98(\mathrm{~m}, 1 \mathrm{H}), 3.80(\mathrm{dd}$, 
$1 \mathrm{H}, \mathrm{J}=5.2,10.4 \mathrm{~Hz}), 3.68(\mathrm{dd}, 1 \mathrm{H}, \mathrm{J}=4.4,10.4 \mathrm{~Hz}), 3.53(\mathrm{dd}, 1 \mathrm{H}, \mathrm{J}=2.0,10.8 \mathrm{~Hz})$, $2.84(\mathrm{dd}, 1 \mathrm{H}, \mathrm{J}=2.4,16.4 \mathrm{~Hz}), 2.36(\mathrm{~s}, 3 \mathrm{H}), 2.34(\mathrm{~s}, 3 \mathrm{H}), 2.14(\mathrm{~m}, 2 \mathrm{H}), 2.09$ (s, 3H), $2.02(\mathrm{~m}, 2 \mathrm{H}), 1.95(\mathrm{~s}, 3 \mathrm{H}), 1.83(\mathrm{~s}, 3 \mathrm{H}), 1.78(\mathrm{~m}, 2 \mathrm{H}), 1.11(\mathrm{~d}, 3 \mathrm{H}, \mathrm{J}=6.8 \mathrm{~Hz}), 1.06(\mathrm{~s}$, 9H), 0.97 (s, 3H), 0.93 (s, 3H); ${ }^{13} \mathrm{C}$ NMR (100 MHz, $\left.\mathrm{CDCl}_{3}\right)$ 170.6, 170.6, 169.8, 168.4, 162.1, 153.1, 150.6, 141.7, 135.9, 135.8, 133.2, 133.0, 130.0, 129.9, 128.0, 127.9, 125.9, 117.0, 116.0, 78.6, 76.4, 74.7, 71.7, 66.2, 39.0, 37.2, 30.2, 29.3, 27.9, $27.1,24.2,22.4,21.4,21.4,21.3,21.0,19.2,16.3,12.1,9.4 ;$ IR $v$ max (neat) $/ \mathrm{cm}^{-1}$ $1774,1731,1369,1240,1191 ; \mathrm{m} / z$ (ESIMS) calculated for $\mathrm{C}_{46} \mathrm{H}_{58} \mathrm{O}_{12} \mathrm{SiNa}[\mathrm{MNa}]^{+}$ 853.36, found: 853.4.

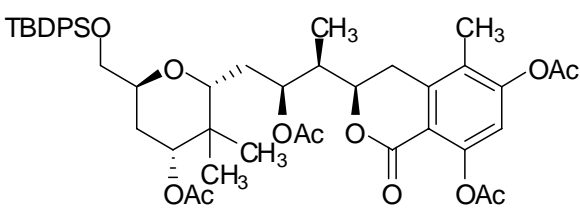

$29 a$

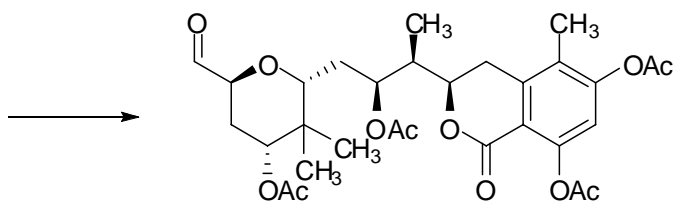

30

To a solution of TBDPS-protected alcohol $(21 \mathrm{mg}, 0.025 \mathrm{mmol})$ in $0.8 \mathrm{~mL}$ pyridine at $0{ }^{\circ} \mathrm{C}$ was added $0.2 \mathrm{~mL} \mathrm{HF}$. pyridine. The mixture was stirred at $0{ }^{\circ} \mathrm{C}$ for $30 \mathrm{~min}$ and then stirred at room temperature for $30 \mathrm{~min}$. The reaction mixture was quenched with $\mathrm{NaHCO}_{3}$ solution and extracted with $\mathrm{CH}_{2} \mathrm{Cl}_{2}$. The combined organic extracts were washed with $1.0 \mathrm{M} \mathrm{HCl}$, dried over $\mathrm{Na}_{2} \mathrm{SO}_{4}$, and then concentrated under reduced pressure. The residue was filtrated through a pad of silica gel with ethyl acetate. The filtrate was concentrated under reduced pressure and dissolved in $1 \mathrm{~mL} \mathrm{CH}_{2} \mathrm{Cl}_{2}$. To the solution was added Dess-Martin reagent (42 $\mathrm{mg}, 0.100 \mathrm{mmol})$. The reaction mixture was stirred at room temperature for $30 \mathrm{~min}$, quenched with water and extracted with $\mathrm{CH}_{2} \mathrm{Cl}_{2}$. The organic layer was dried over $\mathrm{Na}_{2} \mathrm{SO}_{4}$ and concentrated under reduced pressure. The residue was purified by FCC (silica gel, ethyl acetate/hexane $1: 1)$ to give $11 \mathrm{mg}$ compound $29(74 \%)$ as a white foam. $[\alpha]^{25}=+$ $67.6\left(\mathrm{CHCl}_{3}, \mathrm{c}=0.68\right) ;{ }^{1} \mathrm{H} \mathrm{NMR}\left(400 \mathrm{MHz}, \mathrm{CDCl}_{3}\right) ; 9.57(\mathrm{~s}, 1 \mathrm{H}), 6.82(\mathrm{~s}, 1 \mathrm{H}), 5.41$ $(\mathrm{m}, 1 \mathrm{H}), 4.48(\mathrm{dd}, 1 \mathrm{H}, \mathrm{J}=4.8,11.7 \mathrm{~Hz}), 4.36(\mathrm{~m}, 2 \mathrm{H}), 3.38(\mathrm{t}, 1 \mathrm{H}, \mathrm{J}=6.0 \mathrm{~Hz}), 3.15(\mathrm{dd}$, $1 \mathrm{H}, \mathrm{J}=3.0,16.8 \mathrm{~Hz}), 2.92(\mathrm{dd}, 1 \mathrm{H}, \mathrm{J}=10.8,16.8 \mathrm{~Hz}), 2.40(\mathrm{~m}, 1 \mathrm{H}), 2.35$ (s, 3H), 2.34 $(\mathrm{s}, 3 \mathrm{H}), 2.28(\mathrm{dd}, 1 \mathrm{H}, \mathrm{J}=2.0,4.8,13.2 \mathrm{~Hz}) ; 2.10(\mathrm{~s}, 3 \mathrm{H}), 2.07(\mathrm{~s}, 3 \mathrm{H}), 2.06(\mathrm{~s}, 3 \mathrm{H})$, $1.93(\mathrm{~m}, 1 \mathrm{H}), 1.83(\mathrm{~m}, 2 \mathrm{H}), 1.17(\mathrm{~d}, 3 \mathrm{H}, \mathrm{J}=6.9 \mathrm{~Hz}), 0.95(\mathrm{~s}, 3 \mathrm{H}), 0.82(\mathrm{~s}, 3 \mathrm{H}) ;{ }^{13} \mathrm{C}$ NMR (100 MHz, $\left.\mathrm{CDCl}_{3}\right)$ 201.9, 170.8, 170.4, 169.8 168.5, 162.0, 153.2, 150.7, $141.5,126.0,117.1,116.2,79.0,78.0,77.9,73.8,71.8,38.8,37.8,31.1,29.2$, 25.5, 
22.7, 21.5, 21.2, 21.2, 21.0, 13.8, 12.3, 9.4; IR $v$ max (neat) $/ \mathrm{cm}^{-1} 1773,1728,1598$, 1369, 1240, 1192, 1060, 911; $\mathrm{m} / \mathrm{z}$ (ESIMS) calculated for $\mathrm{C}_{31} \mathrm{H}_{41} \mathrm{O}_{13} \mathrm{Na}$ $[\mathrm{MNaMeOH}]^{+}$645.25, found: 645.4.

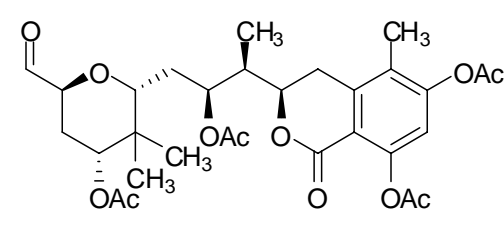

30

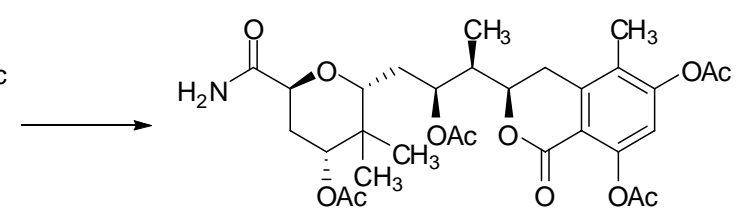

31

To a solution of compound $30(7 \mathrm{mg}, 0.012 \mathrm{mmol})$ in $0.7 \mathrm{~mL} t$-butanol and $0.18 \mathrm{~mL}$ water at room temperature was added $\mathrm{NaH}_{2} \mathrm{PO}_{4} \cdot \mathrm{H}_{2} \mathrm{O}(7 \mathrm{mg}, 0.051 \mathrm{mmol})$, 2-methyl2-butene (16 mg, $0.235 \mathrm{mmol}$ ), and $\mathrm{NaClO}_{2}(5.5 \mathrm{mg}, 0.061 \mathrm{mmol})$. The mixture was stirred at room temperature for $1 \mathrm{~h}$, quenched with $1.0 \mathrm{M} \mathrm{HCl}$ solution and then extracted with $\mathrm{CH}_{2} \mathrm{Cl}_{2}$. The combined organic extracts were dried over $\mathrm{Na}_{2} \mathrm{SO}_{4}$ and concentrated under reduced pressure. The residue was filtrated through a pad of silica gel with acetic acid/ethyl acetate (1: 50). The filtrate was concentrated under reduced pressure and dissolved in $1 \mathrm{~mL} \mathrm{CH}_{2} \mathrm{Cl}_{2}$. To the solution was added 1 drop of DMF and 1 drop of oxalyl chloride. The reaction mixture was stirred at room temperature for $30 \mathrm{~min}$ and concentrated to dryness under reduced pressure. The residue was dissolved in $\mathrm{CH}_{2} \mathrm{Cl}_{2}$ and cooled to $-78{ }^{\circ} \mathrm{C}$. To the stirring solution was passed through $\mathrm{NH}_{3}$ gas for $2 \mathrm{~min}$. The mixture was stirred at $-78{ }^{\circ} \mathrm{C}$ for additional $5 \mathrm{~min}$, quenched with $1.0 \mathrm{M} \mathrm{HCl}$ and then extracted with $\mathrm{CH}_{2} \mathrm{Cl}_{2}$. The organic layer was dried over $\mathrm{Na}_{2} \mathrm{SO}_{4}$ and concentrated under reduced pressure. The residue was purified by FCC ( silica gel, ethyl acetate) to give $6 \mathrm{mg}$ compound $\mathbf{3 1}(83 \%)$ as a white foam. $[\alpha]^{25}{ }_{\mathrm{D}}=+$ $29.6\left(\mathrm{CHCl}_{3}, \mathrm{c}=0.27\right) ;{ }^{1} \mathrm{H} \mathrm{NMR}\left(400 \mathrm{MHz}, \mathrm{CDCl}_{3}\right) ; 6.83(\mathrm{~s}, 1 \mathrm{H}), 6.82(\mathrm{br}, 1 \mathrm{H}), 5.52$ (br, 1H), $5.29(\mathrm{~m}, 1 \mathrm{H}), 4.83(\mathrm{dd}, 1 \mathrm{H}, \mathrm{J}=4.0,8.4 \mathrm{~Hz}), 4.38(\mathrm{~m}, 2 \mathrm{H}), 3.46(\mathrm{dd}, 1 \mathrm{H}, \mathrm{J}=$ 2.0, $10.8 \mathrm{~Hz}$ ), 3.05 (dd, 1H, J=2.4, $16.8 \mathrm{~Hz}), 2.79$ ( dd, 1H, J=12.0, $16.4 \mathrm{~Hz}) 2.35$ (s, $3 \mathrm{H}), 2.33(\mathrm{~s}, 3 \mathrm{H}), 2.26(\mathrm{ddd}, 1 \mathrm{H}, \mathrm{J}=4.4,5.6,13.6 \mathrm{~Hz}), 2.10(\mathrm{~m}, 2 \mathrm{H}), 2.08(\mathrm{~s}, 3 \mathrm{H})$, $2.06(\mathrm{~s}, 3 \mathrm{H}), 1.91(\mathrm{ddd}, 1 \mathrm{H}, \mathrm{J}=5.2,8.4,13.2 \mathrm{~Hz}), 1.79$ (ddd, 1H, J= 2.4, 4.8, $14.8 \mathrm{~Hz}$ ), $1.17(\mathrm{~d}, 3 \mathrm{H}, \mathrm{J}=7.2 \mathrm{~Hz}), 0.95(\mathrm{~s}, 3 \mathrm{H}), 0.94(\mathrm{~s}, 3 \mathrm{H}) ;{ }^{13} \mathrm{C} \mathrm{NMR}\left(100 \mathrm{MHz}, \mathrm{CDCl}_{3}\right)$ 173.6, 171.3, 170.2, 169.8, 168.5, 161.8, 153.3, 150.8, 141.3, 125.9, 117.2, 116.0, 79.8, 78.6, 77.4, 73.7, 72.4, 40.7, 37.2, 30.9, 29.0, 27.6, 24.4, 21.7, 21.3, 21.2, 21.0, 17.0, 12.4, 9.7; IR $v$ max (neat) $/ \mathrm{cm}^{-1} 2978,1773,1725,1684,1593,1370,1241,1192$, 1060, 907; $\mathrm{m} / \mathrm{z}$ (ESIMS) calculated for $\mathrm{C}_{30} \mathrm{H}_{39} \mathrm{NO}_{12} \mathrm{Na}$ [MNa] $]^{+}$628.24, found: 628.4. 